\title{
ODWAGA CYWILNA. GRANICE POJĘCIA W PERSPEKTYWIE SPRAWIEDLIWOŚCI EKONOMICZNEJ
}

Bartosz Mika

Uniwersytet Gdański

\section{/// Wstęp}

Pierwsze intuicje dotyczące odwagi cywilnej kierują socjologa w stronę skojarzeń tego pojęcia z dobrze znanymi terminami, takimi jak: społeczeństwo obywatelskie, nieposłuszeństwo obywatelskie, instytucja strażnicza, sygnaliści czy ruchy społeczne. W prezentowanym artykule spróbujemy wykorzystać wymienione intuicje, choć nasza perspektywa będzie zawierała także elementy analizy socjoekonomicznej. Za tym ostatnim stwierdzeniem kryje się założenie, że żadnego zjawiska społecznego nie da się w pełni i satysfakcjonująco wyjaśnić bez odniesienia do struktury ekonomicznej, jak również przekonanie, że sama struktura ekonomiczna jest obszarem złożonych stosunków społecznych.

Celem artykułu będzie próba odpowiedzi na pytanie: czy we współczesnym ideale odwagi cywilnej mieści się również opór wobec przemocy o podłożu ekonomicznym? Czy na te - tradycyjnie zaliczane do sfery interesów materialnych - zagadnienia można spojrzeć przez pryzmat odwagi cywilnej? Wydaje się, że w definicji pojęcia odwagi cywilnej (skrótowo OC) nie ma niczego, co by dyskwalifikowało zagadnienia ekonomiczne - czy szerzej ekonomiczno-społeczne - z zakresu tego pojęcia. Praktyka społeczna i teoretyczna jest jednak - jak sądzimy - inna, interesy o podłożu materialnym bywają często analizowane jako partykularne, a więc niespełniające warunku obrony interesów ogólnospołecznych. Dychotomie spopularyzowane przez Ingleharta (wartości materialne i postmaterialne) oraz Offego (nowe i stare ruchy społeczne) sankcjonują takie stanowisko. 
Opozycja między materialnym a partykularnym interesem oraz uniwersalistycznymi postulatami ogólnospołecznymi wydaje się dobrze zakorzeniona w socjologii.

W dalszej części tekstu podejmiemy próbę wyjścia poza ten schemat. Spróbujemy wykazać, że zaliczenie do aktów odwagi cywilnej działań wymierzonych w niesprawiedliwość ekonomiczną może nie tylko być owocne poznawczo, ale również mieć pozytywny wpływ na jakość społeczeństwa obywatelskiego. Posłużymy się w tym celu przykładami ruchów społecznych i masowych zrywów niezadowolenia, które przetoczyły się przez świat w ostatnich latach. Spróbujemy wykazać, że przesłanki ich zaistnienia oraz działania nie mieszczą się w przywołanych wyżej dychotomicznych schematach.

Zanim jednak przejdziemy do zasadniczej części tekstu, spróbujmy nieco bardziej systematycznie zdefiniować pojęcie odwagi cywilnej.

\section{/// 1. Próba definicji i zarysowania obszarów problemowych}

\section{/// 1.1. Źródłosłów pojęcia}

Słownik języka polskiego z 2006 roku lakonicznie definiuje odwagę cywilna jako „śmiałość wypowiadania własnych sądów bez względu na opinię publiczną i skutki”. Definicja ta odsyła do pojęcia: „cywilny”, oznaczającego: 1) brak kontaktu z wojskiem, 2) odniesienie do prawnej strony stosunków osobistych oraz 3) przestarzale, obywatelski, osobisty ${ }^{1}$. Ostatnie ze znaczeń wydaje się mieć bezpośredni związek z odwaga cywilną w interesującym nas tu sensie. Na podstawie przytoczonej genezy etymologicznej przyjąć możemy, że pojęcie odwaga cywilna jest zbitką terminów określającą pozawojskowy, odniesiony do stosunków osobistych i społecznych sposób prezentowania własnych sądów.

Metodologia nauk społecznych naucza, że pojęcia potoczne przenikające do języka socjologii (czy innych nauk) należy traktować z ostrożnością. Odwaga cywilna jest tego dobrym przykładem. Zdaniem Stefana Nowaka potocznie rozumiana odwaga cywilna to pojęcie dyspozycyjne odnoszące się do działania, które identyfikujemy w podmiocie (Nowak 2010). Pojęcia tego rodzaju sa szczególnie podatne na definiowanie ich w sposób tautologiczny. Nowak pisał: „wyjaśniamy czyjeś odważne wystapienie publiczne

\footnotetext{
1 W związku z archaicznością pojęcia cywilny, potocznymi korzeniami tego określenia i jednocześnie osadzeniem odwagi cywilnej w kontekście społeczeństwa obywatelskiego warto być może rozważyć zmianę terminologiczną i zamiast odwagi cywilnej używać terminu odwaga obywatelska.
} 
powołaniem się na jego charakterologiczne dyspozycje: powiadamy, że zachowuje się on tak właśnie, ponieważ ma odwagę cywilną. Jednakże termin «odwaga cywilna» oznacza ten właśnie sposób zachowania się, który chcielibyśmy wyjaśnić. «Prawo», którym milcząco posługujemy się w wyjaśnianiu - głosząc, iż ludzie mający odwagę cywilną tak właśnie się zachowuja - okazuje się tautologia definicyjną" (Nowak 2010: 267).

Potocznie odwaga cywilna jest postawą lub dyspozycją jednostkową związaną z wysokim standardem moralnym. Najczęściej wymieniane przejawy występowania odwagi cywilnej mówią o jednostkowych aktach sprzeciwu w obliczu przewagi i siły grupy. Odwaga cywilna jest - w powszechnym odczuciu - rozumiana jako zdolność do oporu jednostki wobec owej siły niezależnie od indywidualnych kosztów. Scharakteryzowane w ten sposób, krytykowane przez Nowaka, potoczne rozumienie odwagi cywilnej zawiera paradoks ważny ze względu na tautologiczność pojęcia.

Odwaga cywilna opisywana jest jako akt jednostkowy i jednocześnie silnie zakorzeniony społecznie. Ważny jest nie tylko fakt aktywnego wystąpienia przeciw sile grupy, ale również przełamanie własnego strachu w obliczu możliwych sankcji negatywnych (także tych oddalonych w czasie) oraz orientacja na szeroki system norm, wartości, postaw i interakcji.

Wystawienie na ryzyko w sytuacjach wymagających odwagi cywilnej, manifestacja odwagi w imię wyższych wartości, stało się punktem wyjścia badań psychologów społecznych.

\section{/// 1.2. Badania psychologów społecznych}

W końcu lat 60. oraz w latach 70. Latané oraz Darley (1968, 1969, 1970, 1976) poświęcili wiele uwagi czynnikom decydującym o udzieleniu pomocy ofiarom przez przypadkowego świadka zdarzenia zaburzającego rutynowe funkcjonowanie przestrzeni publicznej. Bobb Latané (1969) próbował wyjaśnić zjawisko nazywane syndromem Genovese ${ }^{2}$. Polega on na uchylaniu się od pomocy w sytuacji, kiedy określone zdarzenie ma miejsce na oczach wielu świadków. Zgodnie z ustaleniami cytowanego autora ludzie są bardziej skłonni do pomocy, kiedy stają oko w oko z problemem lub kiedy przebywają w towarzystwie żnaczqcego innego. Latané (1969)

\footnotetext{
${ }^{2}$ Catherine Genovese była młodą mieszkanką Nowego Yorku. W 1964 roku została napadnięta i zamordowana na oczach sąsiadów. Media donosiły wówczas o 38 świadkach zdarzenia, którzy zachowali całkowitą bierność w sytuacji zagrożenia. W 2007 roku Rachel Manning, Mark Levine i Alan Collins podważyli relację mówiącą o 38 świadkach, podkreślając jednocześnie doniosłość całej sprawy dla inicjowania badań nad zagrożeniem, wypadkami i zachowaniem świadków takich zdarzeń.
} 
wskazał, że podjęcie pomocy wymaga od świadka zdarzenia przejścia przez kilka stadiów procesu decyzyjnego, wśród których wyszczególnił m.in.: uznanie przez świadka realności zagrożenia oraz przyjęcie przez niego indywidualnej odpowiedzialności. Proces ten jest zaburzony, kiedy odpowiedzialność jest rozproszona, co ma miejsce w obecności anonimowych świadków. Podobnie jak w przypadku tragicznej śmierci Kitty Genovese anonimowi świadkowie zniechęcają do podejmowania działań pomocowych.

Wiele lat później, opierając się na ustaleniach Latanégo i Darleya (1970), zespół Greitemeyera przyjął hipotezę, że opisywane przez ich poprzedników zachowania pomocowe (helping behavior) nie są tożsame z odwaga cywilna. Gdyby było inaczej - zakładano - świadkowie zdarzeń takich jak atak na Kitty Genovese wykazaliby się odwagą i powstrzymali napastników. Różnica polega na tym, że w tego rodzaju sytuacjach to nie odwaga cywilna jest ważna, ale udzielenie pomocy. Greitemeyer wraz ze współpracownikami definiuje interesujące nas pojęcie jako „odważne zachowanie, któremu towarzyszy gniew i oburzenie, zmierzające do egzekwowania społecznych lub etycznych norm bez względu na koszty społeczne" (2007: 115).

Weryfikując swoje założenia empirycznie, zespół Greitemeyera postanowił kontrolować dwie zmienne: obecność świadków oraz nastrój działającego. Po przebadaniu wpływu obu czynników na zachowania prospołeczne oraz odwagę cywilną cytowany zespół dowodził, że w przypadku okazywania pomocy działanie było uzależnione od obecności pasywnych obserwatorów oraz nastroju ${ }^{3}$, natomiast akty cywilnej odwagi były niezależne od obu tych warunków. Autorzy konkludują, że odwagę cywilną należy osadzić w szerszym kontekście odwagi moralnej (Putnam 1997) i wiążą ja z poczuciem sprawiedliwości i specjalnym rodzajem asertywności. W takim wypadku OC wiąże się nie tyle z altruizmem i zdolnością do niesienia pomocy, ile raczej z gotowościa do poniesienia osobistej odpowiedzialności, wystawienia się na ryzyko w imię wyższych wartości.

Stosując przywołaną wyżej definicję odwagi cywilnej, Osswald, Frey oraz Streicher (2012) podkreślali odrębność tego pojęcia od kontroli społecznej oraz zachowań pomocowych. Odwaga cywilna różni się od spontanicznej kontroli społecznej - w rutynowych sytuacjach - silniejszą orientacją altruistyczną oraz większą doniosłością uniwersalnych reguł społecz-

\footnotetext{
${ }^{3}$ Jak powiedziano, obecność obserwatora zmniejsza prawdopodobieństwo niesienia pomocy (jak w klasycznych badaniach Latanégo). Podobnie działa neutralny nastrój. Ludzie chętniej pomagają, aby potrzymać swój dobry nastrój lub poprawić zły.
} 
nych. Ponadto w porównaniu z zachowaniami pomocowymi i kontrola społeczną, OC jest również silniej zakorzeniona w normach uznawanych w danym społeczeństwie za powszechne (Osswald, Frey oraz Streicher 2012). Na ten ostatni aspekt odwagi cywilnej zwracał uwagę także Miller, podkreślając, że zagadnienie to w mniejszym stopniu dotyczy „ryzyka, hazardu czy koniecznych do pokonania przeszkód, a bardziej wartości, cnót, norm, a także tego, co uznawane za słuszne" (2000: 36).

Silna orientacja moralna stojąca za odwagą cywilna przekłada się na pozytywną rolę gniewu (anger) w inicjowaniu aktów OC. Halmburger, Baumert i Schmitt (2015) wykazali, że silna reakcja emocjonalna (oburzenie i gniew bardziej niż poczucie winy) sprzyja przyjęciu przez jednostkę odważnej postawy. Osoba znajdująca się w sytuacji wymagającej odwagi łatwiej się na nią zdobędzie, jeśli obserwowane zachowanie wzbudza w niej negatywną reakcję emocjonalną.

Reasumując, postulowane przez psychologów społecznych umieszczenie pojęcia odwagi cywilnej w kontekście poczucia sprawiedliwości i odpowiedzialności pozwala w znacznym stopniu przekroczyć opisaną wyżej tautologiczność definicji ograniczającej się jedynie do indywidualnych dyspozycji jednostki. Dyspozycje jednostkowe są istotne, ale w przypadku pojęcia tak silnie zakorzenionego społecznie trudno je oddzielić od systemu normatywnego, poczucia sprawiedliwości, gniewu wywołanego aktem złamania przyjętej lub uznanej za właściwą normy. Istotne jest również ryzyko poniesienia negatywnych, społecznych konsekwencji, które Greitemeyer i in. (2007) oraz Osswald i in. (2012) uznaja za konstytutywne dla odwagi cywilnej.

\section{/// 1.3. Społeczeństwo obywatelskie, zaufanie i odwaga cywilna}

Z socjologicznego punktu widzenia opracowania cytowanych wyżej psychologów społecznych mają jedną słabą stronę; w najlepszym razie lakonicznie odnoszą się do relacji między naruszeniem norm (w wyniku którego dochodzi do manifestacji odwagi cywilnej) a porządkiem makrospołecznym, przyjmując milcząco, że porządek ten jest znany i powszechnie podzielany. Tymczasem - szczególnie we współczesnych, rozwiniętych społeczeństwach - nierzadko dochodzi do sytuacji antynomii normatywnej, czyli występowania w tym samym czasie odmiennych regulacji w obrębie różnych systemów normatywnych (np. niespójności prawa z moralnością lub obyczajem). Jeśli ktoś wystąi w obronie szykanowanego przedstawiciela mniejszości w państwie apartheidu, nie broni obowiązujących reguł 
prawnych, ale wręcz je narusza, a przecież skłonni jesteśmy uznać takiego kogoś za odważnego cywilnie.

Trudność tę dostrzega i artykułuje Richard Swedberg (1999). Autor ten odnosi się do pokrewnego przykładu, pytając: czy rasista wygłaszający swoje poglądy wobec audytorium niepodzielającego jego poglądów prezentuje odwagę cywilną? Odpowiedź może być zdaniem cytowanego autora jedna: nie, taki nonkonformista (lub prowokator) nie prezentuje odwagi cywilnej. Swedberg uznaje, że OC jest pojęciem umieszczonym w kontekście nowożytnego społeczeństwa obywatelskiego, a więc ściśle odnoszącym się do jego systemu wartości. W takim ujęciu przykładowy rasista nie przejawia odwagi cywilnej, występuje bowiem przeciw tym wartościom. Oczywiście odpowiedź Swedberga nie rozstrzyga zagadnienia wystarczająco, ponieważ nie rozwija kwestii, o jaki rodzaj lub typ społeczeństwa obywatelskiego chodzi? Satysfakcjonujące rozwiązanie przynosi zamieszczony w niniejszym tomie tekst Mikołaja Rakusy-Suszczewskiego, według którego klasyfikacja poszczególnych działań jako aktów odwagi cywilnej (lub odmówienie im tego statusu) odbywa się zawsze na gruncie przyjętej definicji sfery publicznej. Zatem uznanie określonych działań za przejawy odwagi obywatelskiej zawsze odbywa się na gruncie pewnej definicji. Swedberg przyjmuje milcząco określoną definicję społeczeństwa obywatelskiego i na jej gruncie dokonuje klasyfikacji działania przykładowego rasisty.

Zatem klasyfikując poszczególne akty jako akty odwagi cywilnej, musimy pamiętać, że społeczeństwo obywatelskie jest terminem łączącym w sobie pewną ambiwalencję: „w bardziej pobieżnych rozważaniach często dochodzi do pomylenia opisu rzeczywistości z pewnym projektem normatywnym. Raz jest to bowiem próba scharakteryzowania dokonujących się procesów emancypacji [...]. Innym razem próbuje się poszukiwać tej idei w społeczeństwie, które funkcjonuje w oparciu o inne, czasami przeciwstawne wartości” (Peisert 2014).

Pamiętając o wzmiankowanych trudnościach definicyjnych związanych z odwaga cywilna, możemy opisać ją jako zakładającą możliwość negatywnych sankcji ${ }^{4}$, jednostkową manifestację na rzecz przywrócenia lub ustanowienia normatywnego lub obyczajowego porządku. Owo przywrócenie zostało tu uzupełnione o słowo ,ustanowienie”, ponieważ odwaga cywilna nie ma jedynie charakteru defensywnego i konserwatywnego (w znaczeniu przywrócenia status quo), ale często wręcz przeciwnie - ma charakter

\footnotetext{
${ }^{4}$ Antycypacja potencjalnych sankcji wydaje się nieodzowna dla uznania danego działania za przejaw odwagi cywilnej. Bez świadomości zagrożenia, bez podjęcia ryzyka nie może być mowy o odwadze.
} 
postępowy, reformatorski, a bywa, że rewolucyjny. Michał Kaczmarczyk (2013: 33) tak opisywał pokrewne odwadze cywilnej nieposłuszeństwo obywatelskie: „nie jest [ono] w tym sensie zwykłym nonkonformizmem, ale otwartym i precyzyjnym wskazywaniem niesprawiedliwości, podważaniem wartości - przypominaniem Platońskiego pytania o dobro”. Zatem socjologicznie rozumiana odwaga cywilna nie odnosi się do ustalonego, powszechnie akceptowanego porządku, ale raczej do porządku wyobrażonego, postulowanego, szlachetniejszego niż zastany. Przykładowo postulaty ruchu LGBT moga nie znajdować poparcia społecznego, jednak ich obrona będzie odwoływała się do zasad równości wobec prawa i godności osobistej. Odwaga cywilna stawania w obronie tych postulatów nie będzie równoznaczna $z$ ich akceptacja, ale raczej z prawem do ich wygłaszania, poszanowania i poważnego traktowania.

Na zakończenie paragrafu warto podkreślić, że odwaga cywilna odnosi się - zgodnie z przyjętą definicją - do aktów indywidualnych. Jednocześnie, jak wykazaliśmy, każde interesujące nas działanie jest silnie zakorzenione społecznie i powinno być rozpatrywane kontekstowo. Ponieważ w dalszej części opracowania będziemy odnosić się do działań o charakterze zbiorowym, ważne jest ustalenie relacji między indywidualnymi aktami odwagi cywilnej a działaniami na poziomie ponadjednostkowym. Dla tych ostatnich nierzadko rezerwuje się pojęcie nieposłuszeństwa obywatelskiego, najczęściej manifestowanego w obrębie określonego ruchu społecznego. Pojęcie to wprowadził do języka nauk społecznych w XIX wieku Henry D. Thoreau, definiując je w kontekście społeczeństwa obywatelskiego. Henning Melber zestawia oba terminy (tj. odwagę cywilną i nieposłuszeństwo obywatelskie), stwierdzając, że „można założyć [...], iż poszczególne formy nieposłuszeństwa obywatelskiego wymagają odwagi cywilnej, by zaistnieć" (2001: 235). Również przykłady indywidualnych aktów odwagi cywilnej opisywane przez Barbarę Misztal (2007) i Richarda Swedberga (1999) dowodza, że poszczególne akty odwagi mogą być konstytutywne dla szerszej społecznej kontestacji (czyli tego, co Swedberg nazwał innowacja normatywna) i odwrotnie, poszczególne działania zbiorowe mogą być inicjowane i podtrzymywane dzięki odwadze cywilnej.

Łącząc pojęcie odwagi cywilnej z określoną wizja ładu społecznego, sfery publicznej, porządku moralnego, definicji obywatelstwa, podkreślić należy - jak czyni Mikołaj Rakusa-Suszczewski w niniejszym tomie - że odwaga cywilna to specyficzny rodzaj odwagi nawiązujący bardziej do obywatelstwa niż indywidualnych standardów moralnych. Każde z tych podjęć zawiera w sobie również potencjał oporu i niezgody oraz postulat zmiany 
zastanego stanu rzeczy. Związek OC z działaniami ponadjednostkowymi wydaje się więc bliski. Można przyjąć, że żaden ruch społeczny nie obędzie się bez odwagi cywilnej w szeregach jego członków, natomiast żaden akt odwagi cywilnej nie miałby miejsca, gdyby nie obecność w przestrzeni publicznej wartości, do których się odnosi. Jeśli są to wartości awangardowe, to przeważnie ich postulatorem - w państwach demokratycznych - są ruchy społeczne.

Pytanie, które chcemy postawić w dalszej części tekstu, brzmi: czy $\mathrm{w}$ tak zdefiniowanej odwadze cywilnej postulat szlachetniejszego społeczeństwa może dotyczyć również interesów klasowych, materialnych, tradycyjnie kojarzonych ze „starymi ruchami społecznymi”?

\section{/// 2. Obrona interesów klasowych jako przejaw odwagi cywilnej}

W istocie powyższe pytanie składa się z dwóch części: czy idea sprawiedliwości mieści w sobie również sprawiedliwość podziału dóbr materialnych oraz czy współczesne ruchy manifestujące interes klasowy moga odgrywać rolę rzeczników tak rozumianej sprawiedliwości? Na oba te pytania można odpowiedzieć, sięgając do dowodów empirycznych.

\section{/// 2.1. Sprawiedliwe społeczeństwo społeczeństwem egalitarnym}

Posługując się badaniami eksperymentalnymi, możemy przyjać, że jedna z cech wspólnych większości ludzi jest elementarne poczucie sprawiedliwości. Międzynarodowe badania Josepha Henricha (2004) i jego współpracowników potwierdzają istnienie czegoś, co można określić jako „zmysł sprawiedliwości”. Zespół naukowców przeprowadził eksperyment w 15 krajach świata, zachowując daleko idąca różnorodność doboru uczestników ${ }^{5}$ i opierając się na grze w ultimatum. W tej prostej grze udział biorą dwie osoby. Pierwsza z nich otrzymuje od eksperymentatora określona ilość pieniędzy i zostaje poproszona o przekazanie dowolnej, uznanej przez siebie za stosowną części tej kwoty drugiemu uczestnikowi eksperymentu. Kiedy druga osoba odmówi przyjęcia zaproponowanej sumy, pieniędzy nie otrzymuje żaden z grających, gdy ja przyjmie, obydwie osoby zachowuja swój udział. Istotą eksperymentu opartego na ultimatum jest wykazanie, że niesprawiedliwa propozycja podziału pieniędzy spotka się z odrzuceniem. Okazało się, że mimo uchwycenia szeregu różnic społecznych, demogra-

${ }^{5}$ Jednym z celów metodologicznych badania było wyjście poza najczęściej badane populacje studentów uniwersytetów zlokalizowanych w wielkich miastach. 
ficznych i ekonomicznych pomiędzy uczestnikami zasadą sprawdzającą się wszędzie było decydujące znaczenie poczucia sprawiedliwości.

Niedawno zaprezentowane wyniki badań Sorapopa Kiatpongsana oraz Michaela I. Nortona zdają się pokazywać podobne tendencje. Autorzy wykorzystali wyniki sondażu przeprowadzonego w grudniu 2012 roku w ramach Programu Międzynarodowych Badań Społecznych (International Social Survey Programme - ISSP). W badaniach tych respondenci z 40 państw (w tym z Polski) zostali zapytani, ile ich zdaniem zarabia prezes spółki giełdowej, minister rządu oraz niewykwalifikowany robotnik, a także ile ich zdaniem powinni zarabiać ludzie zajmujący te pozycje społeczne. Kiatpongsan oraz Norton zestawili odpowiedzi respondentów z wynikami badań OECD dla 16 krajów (w tym Polski) obrazującymi faktyczne zarobki prezesów spółek (w Polsce spółek WIG20, dla których średnia wyniosła 1,8 miliona złotych rocznie). Wyniki zestawień wykonanych przez Kiatpongsana oraz Nortona dowodzą wysokiego poczucia egalitaryzmu wśród respondentów. Średnia różnica między wynagrodzeniem prezesa a robotnika powinna wynosić zdaniem badanych 4,6 raza więcej. Oczywiście respondenci nie byli naiwni i wiedzieli, że faktyczne różnice są większe, szacowali je średnio na 10 razy więcej (przy dużych różnicach międzynarodowych, od 3,7 w Danii do prawie $42 \mathrm{w}$ Korei Południowej). Polscy respondenci uważali, że prezes spółki zarabia 14 razy więcej od robotnika niewykwalifikowanego. Tymczasem rzeczywisty wskaźnik różnic wynosił dla Polski $28^{6}$.

Najbardziej interesujące z naszego punktu widzenia jest jednak to, że silne egalitarne postawy - zakładające niewielką rozbieżność między zarobkami prezesów a robotników niewykwalifikowanych - cechowały się wysoką inwariancją od głównych różnic społeczno-demograficznych. Innymi słowy populacja badanych była zgodna co do kształtu idealnej drabiny zarobków i raczej naiwna w ocenie jej rzeczywistego kształtu.

W świetle przywołanych badań - a nie należą one do wyjątków - możemy powiedzieć, że sprawiedliwość ekonomiczna stanowić może składnik idealnego, postulowanego społeczeństwa, do którego odwołuje się jednostka przejawiająca odwagę cywilną. Ponadto taki postulat koresponduje z ogólnym dobrostanem społeczeństwa. Jak dowodzili Pickett i Wilkinson (2011), kraje bardziej egalitarne cieszą się wyższym poziomem zaufania społecznego (należą do nich zwłaszcza kraje skandynawskie, Holandia oraz Japonia) oraz zdrowia publicznego. Zdrowsze, bardziej ufne społeczeństwo ma zapewne większe szanse na upowszechnienie cywilnej odwagi (choć teza ta ma charakter pewnej, wymagającej dowodów spekulacji).

${ }^{6}$ W USA wskaźniki te wyniosły: idealny 7, antycypowany 30, faktyczny 350 . 
Wracając jednak do głównego wątku, czyli pytania o miejsce sprawiedliwości ekonomicznej w ogólnym pojęciu sprawiedliwości, warto wskazać, że opisane wyżej postawy egalitarne znajduja swój wyraz w politycznych postulatach traktowania praw socjalnych jako integralnej części praw człowieka. Przykładowymi propozycjami w tej materii są naciski na pełną realizację minimalnego dochodu wynikającego z Europejskiej Karty Społecznej oraz Karty Podstawowych Praw Socjalnych Pracowników WE (Szarfenberg 2014) czy postulaty wprowadzenia dochodu podstawowego (Van Parijs 2014, Standing 2004). Wydaje się, że stworzenie kompleksowej teorii sprawiedliwości bez uwzględnienia - mówiąc językiem Parsonsa podsystemu ekonomicznego jest trudne do wyobrażenia (Rawls 1994).

\section{/// 2.2. Klasa uniwersalna i gniew klasowy}

Drugie z postawionych wyżej pytań cząstkowych odnosiło się do sposobu realizacji postulatu sprawiedliwości albo - mówiąc precyzyjniej - do agentów tej zmiany. Dokładniej jest to pytanie dotyczące tego, czy ruch robotniczy - lub inny ruch o klasowym charakterze - może przyjąć na siebie rolę rzeczników tego interesu. Uważny czytelnik z pewnością dostrzeże, że przyjmujemy tu pewne milczące założenia odnoszące się do porządku społeczno-gospodarczego. Przykładowo uznajemy klasy społeczne za zbiorowości zakorzenione w gospodarce, wyróżnione ze względu na miejsce zajmowane w podziale pracy i własności, które wciąż zachowują doniosłą rolę w reprodukcji ładu społecznego. Inaczej mówiąc, uznajemy - choć nie będziemy tego rozwijać - współczesne społeczeństwo za społeczeństwo klasowe, w którym różnice interesów poszczególnych klas społecznych, relacje między nimi oraz dynamika ścierania się owych interesów odgrywają kluczową rolę.

Zatem czy klasy społeczne i ich polityczni reprezentanci moga zostać określeni jako ci, którzy wykazują się odwagą cywilną, dążący do sprawiedliwości społecznej? Sądzimy, że istnieją dwa godne rozważenia argumenty teoretyczne oraz fakty empiryczne odnoszące się do najnowszych ruchów protestu, które wskazują na poparcie takiego stwierdzenia.

Zacznijmy od argumentu pragmatycznego. David Ost (2007) w szeroko komentowanej Klesse solidarności wychodzi od tezy mówiącej, że gniew o podłożu ekonomicznym jest cechą immanentną wszystkich rozwiniętych społeczeństw. Ponadto uznaje tę tezę za oczywistość, pisząc: „,...] to, że kapitalizm nieuchronnie rodzi gniew, jest od dawna rzeczą oczywistą dla przedstawicieli nauk społecznych" (Ost 2007: 60). Rodzi się on perma- 
nentnie w miejscu pracy, od etapu produkcji do momentu otrzymywania wynagrodzenia i wejścia na rynek dóbr konsumenckich. „Dziennikarze i przedstawiciele nauk społecznych pisali o protestach robotniczych, odkąd w ogóle pojawili się robotnicy, dlatego możemy stwierdzić, że doświadczenie gniewu ekonomicznego jest także uniwersalne" (tenże: 61). Podczas gdy komentatorzy książki Osta - zgodnie ze słowami samego autora (Ost 2011) - woleli skupić się na wątku zdrady robotników, do której doszło w kręgach liberalnej inteligencji w Polsce, podstawową tezą Klęski solidarności jest konieczność organizowania - w ramach struktur liberalnej demokracji - gniewu klasowego zrodzonego z nierównej pozycji w stosunkach pracy i własności. Ost (2007) jest w tym względzie kategoryczny; gniew tego rodzaju musi zostać zagospodarowany, a usuwanie go poza obszar polityki - jak to miało miejsce zdaniem tego autora w Polsce po 1989 - prowadzi do antyliberalizmu i jest niebezpieczne dla stabilności demokracji. „Jednym słowem tłumienie polityki klasowej [w Polsce] przyniosło skutki nader niekorzystne dla liberalizmu (politycznego) i demokracji. Nie wyeliminowało gniewu zrodzonego na podłożu ekonomicznym, ale przyczyniło się do zorganizowania go po myśli wrogów liberalizmu. Jeśli gniew taki nie zostanie zorganizowany zgodnie z założeniami klasowymi, musi znaleźć sobie inną oś, wokół której będzie się obracał” (tenże: 369). Organizacja niezadowolenia klasowego i włączenie go w procesy demokratyczne ma zatem w ujęciu Osta fundamentalne znaczenie dla stabilności systemu politycznego. Pogląd Osta można zaadaptować do interesującego nas tematu w następujący sposób: wprawdzie postulaty poszczególnych klas społecznych mają często charakter partykularny ${ }^{7}$ - zwłaszcza kiedy mowa o bieżącej polityce - jednak ich włączenie w sferę publiczną niesie uniwersalne korzyści (stabilizując system polityczny).

Użyteczność organizacji niezadowolenia o podłożu ekonomicznym w postaci postulatów klasowych dla społeczeństwa obywatelskiego - oraz pośrednio, odwagi cywilnej-wynika także z tego, że interes materialny ma charakter celowo racjonalny lub - mówiąc językiem Funkcjonalnej Teorii Konfliktu - realistyczny (Coser 1956). Dowody empiryczne i historyczne pokazują, że nawet głębokie podziały tożsamościowe mogą zostać zawieszone lub skutecznie skanalizowane, jeśli członków różnych grup łączy interes ekonomiczny. Przykładowo w Republice Południowej Afryki „opozycja

\footnotetext{
Choć nie zawsze tak jest. Przykładowo istnieje różnica między pielęgniarkami żądającymi bezpośrednich podwyżek a przedstawicielkami tej samej profesji postulującymi mniejszą liczbę godzin pracy i wzrost zatrudnienia do poziomu pozwalającego na pracę, w warunkach kiedy stosunek personelu do pacjentów wynosi (przykładowo) 1 do 5. Pierwszy postulat jest czysto partykularny, drugi ma na uwadze jakość usług medycznych, a wiec jest potencjalnie uniwersalny.
} 
wobec niesprawiedliwości apartheidu oraz żądania większej równości społecznej (włączając w to socjalistyczną alternatywę) nigdy nie były ograniczone do różnic rasowych nałożonych przez państwo" (Melber 2001: 239). Podobnie na ziemiach polskich w początkowej fazie rewolucji 1905 roku, kiedy przedstawiciele różnych partii (PPS, SDKPiL) oraz różnych wyznań i narodowości (np. Żydzi i Polacy) walczyli ramię w ramię. Analogiczne procesy obserwowano w 2014 roku w Bośni i Hercegowinie: „w Mostarze, wielkim mieście w Hercegowinie, od zawsze podzielonym na dzielnice chorwacką i bośniacka, obywatele wyszli na ulice razem - pierwszy raz od końca wojny" (Derens 2014: 10). Znamienne, że przytoczone przykłady zrywów społecznych miały charakter uniwersalistyczny, odwołujący się do idei sprawiedliwości. Walcząca z uciskiem rasowym i ekonomicznym ludność RPA, robotnicy Królestwa Polskiego, mieszkańcy Bośni i Hercegowiny, wszyscy występowali powodowani ekonomiczną niesprawiedliwością (w przypadku RPA silnie uwarunkowaną rasowo), ale ich postulaty odwoływały się do wyższych wartości.

Inny argument przemawiający za traktowaniem postulatów klasowych w kategoriach odwagi cywilnej ma charakter uniwersalistyczny. Jest nim oczywiście znana, oparta na filozofii Karola Marksa „klasa uniwersalna”. Michał Kaczmarczyk (2013: 36) napisał o niej: „stojąca na straży interesów człowieka «jako gatunku» - specyficzna formuła zawężająca wprawdzie dobro ludzkości do losu robotników, ale z uwagi na postęp całego społeczeństwa”. Nie jest to zdanie całkiem ścisłe z uwagi na ryzyko mylnego utożsamienie losu robotnika z jego interesem. Filozofia Marksa koncentruje się na proletariacie z uwagi na jego miejsce w stosunkach społecznych, w stosunkach własności prywatnej, nie zaś ze względu na jego - partykularnie pojmowany - interes. Dobrze wykłada to Tomasz R. Wiśniewski (2013: 74), pisząc: „ujawnienie tego, że własność prywatna jest w istocie stosunkiem społecznym, w dodatku stosunkiem złożonym, który «kryje w sobie stosunek własności prywatnej jako pracy, stosunek własności prywatnej jako kapitalu, oraz wzajemny stosunek jednego i drugiego», pozwala $\mathrm{mu}$ [Marksowi] na ukazanie epistemologicznego znaczenia panujących stosunków społecznych". Dlatego właśnie ruch robotniczy jest ruchem, którego celem ,nie jest dokonanie [tylko] przewrotu politycznego, lecz przewrotu poznawczego” (tenże: 76). W Ideologii niemieckiej Marks pisze: „aby pozwolić dojść do głosu swojej osobowości, [robotnicy] muszą znieść swój

\footnotetext{
${ }^{8}$ Należy dodać, że wraz z rozwojem rewolucji do głosu dochodzą siły narodowe, które zaczynaja używać antysemityzmu jako broni politycznej. Przykład ten pokazuje, że przynależności o charakterze tożsamościowym i klasowym znajdują się w ciagłym napięciu (zob. Piskała, Marzec 2013).
} 
dotychczasowy warunek egzystencji, będący warunkiem istnienia całego dotychczasowo społeczeństwa, pracę" (1961: 86). Marksowi nie chodzi przy tym o zniesienie pracy w ogóle - wbrew krytykom Marks daleki był od naiwności - a pracy wyobcowanej (lub mówiąc językiem Kapitału - pracy abstrakcyjnej). Celem ruchu robotniczego nie jest więc walka o swój interes, ale zniesienie całego obowiązującego porządku społecznego, w obrębie którego praca najemna i kapitał tworzą warunki alienacji i zaprzeczenia wolności podmiotowej. Jedynie praca uwolniona od własności prywatnej może być wolna. Praca może być zaś wolna „pod dwoma niezbędnymi warunkami: że będzie wolną działalnością pracującego podmiotu [a więc nie będzie wynikała z przymusu ekonomicznego] oraz że będzie wynagradzana według - w wolny sposób - ustanowionych reguł" (Wiśniewski 2013: 74). Proletariat więc prowadzi swoją walkę nie tylko we własnym interesie, ale w interesie - jak pisał Marks - całego gatunku. Zniesienie pracy najemnej, pracy abstrakcyjnej przyniesie wolność (słynne „królestwo wolności”) wszystkim, nie tylko proletariatowi.

Warto nadmienić, że oba przytoczone powyżej argumenty teoretyczne stanowią od dekad oś zażartego sporu, którego nie będziemy tu relacjonować. Nie chcemy w tym miejscu rozstrzygać, czy orientacja socjaldemokratyczna stanowi jeden $z$ instrumentów realizacji postulatu klasy uniwersalnej, czy też jest jego zaprzeczeniem. Z punktu widzenia odwagi cywilnej ważne jest, że obie linie argumentacyjne pozwalają uznać odwagę w sytuacjach ekonomicznej opresji za rodzaj odwagi cywilnej. W obu przypadkach - choć może to prowadzić do różnych postulatów politycznych - w ideale społeczeństwa mieści się również ideał sprawiedliwości ekonomicznej.

\section{/// 3. Ruchy oburzenia i niezadowolenia}

Stosując klasyczny dziś podział Clausa Offego (1995) na stary i nowy paradygmat ruchów społecznych, łatwo przyjąć tezę, że obrona interesów materialnych mieści się w tym pierwszym typie i ma charakter partykularny. Stare ruchy społeczne cechowały się zdaniem niemieckiego socjologa hierarchiczną organizacją, stabilną struktura, zakorzenieniem politycznym oraz odwołaniem do interesu materialnego poszczególnych klas społecznych. Tak rozumiany interes był partykularny i odnosił się - najczęściej do postulatów innej, czyli zgodnej z interesem określonej klasy (lub tylko jej części - np. robotników danej branży) redystrybucji dóbr. Starym ruchom społecznym (głównie zorganizowanym w postaci związków zawodowych i partii) Offe przeciwstawiał nowe ruchy odwołujące się - przez postulaty 
uznania - do praw uniwersalnych. Ruchy praw kobiet, emancypacji mniejszości rasowych i etnicznych, praw osób LGBT, ruchy ekologiczne, pacyfistyczne - wszystkie one zmierzały do uznania własnych praw, ale w imię bardziej sprawiedliwego społeczeństwa.

Stosując binarny podział na stare i nowe ruchy społeczne, łatwo zaklasyfikować partykularne i materialne postulaty klasowe za niemieszczące się w definicji odwagi cywilnej, natomiast tożsamościowe, postmaterialne ${ }^{9}$ i zgłaszające pretensje do uniwersalności postulaty „nowych ruchów” za odważne cywilnie. Problem polega na tym, że „empiryczne przykłady współczesnych ruchów społecznych nie mogą być łatwo zaklasyfikowane jako «stare» lub «nowe», ponieważ świat materialny jest zwyczajnie bogatszy niż teoretyczne próby jego prezentacji”' (Baranowski 2013: 10). Mariusz Baranowski ma tu na myśli łagodniejszą wersję deklaracji Lorny Weir (1993), zgodnie z którą obstawanie przy ścisłym podziale nowych i starych ruchów społecznych (lub - jak pisze autorka - ruchów sprzed II wojny światowej i po niej) wynika $z$ ortodoksyjnego traktowania ruchu robotniczego. Ten ostatni rzadko miał charakter czysto instrumentalny i partykularny. Przytoczony wyżej przykład rewolucji 1905 w Królestwie Polskim pokazuje, że wraz z postulatami materialnymi podnoszono także kwestie autonomii politycznej, praw kobiet, dostępu do edukacji, a także różnic etnicznych i religijnych ${ }^{10}$.

Niemal sto lat później, w szczycie walk klasowych, które przetoczyły się przez Wielką Brytanię, można było dostrzec tę samą złożoność procesów protestu. W 1984 roku górnicy z zamykanych przez Margaret Thatcher kopalń podjęli się obrony swoich miejsc pracy, jednak szybko zostali sami na placu boju ${ }^{11}$. „W sytuacji, gdy oficjalny ruch robotniczy nie popierał strajku, kluczowe znaczenie miały wszelkie nieformalne akcje na rzecz wspierania górników. Miners' Support Groups (Grupy Wsparcia Górników) pojawiły się w każdym dużym mieście i w każdej społeczności lokalnej, w której istniały kopalnie. Grupy te tworzone były przede wszystkim przez żony strajkujących górników, ale również przez studentów, grupy młodzieżowe, czarną młodzież, gejów i lesbijki"12. Pomimo że strajki i wsparcie dla nich miały charakter walki o interes branżowy, to ich przebieg wyszedł poza

\footnotetext{
${ }^{9}$ Nasuwa się z kolei inna popularna dychotomia - podział na wartości materialne i postmaterialne (Inglehart 1997).

${ }^{10}$ Choć te ostatnie szubko utracily emancypacyjny charakter, by stać się fundamentem antysemityzmu polskich grup narodowych i konserwatywnych.

${ }^{11}$ Liderzy związków innych branż nie przyłączyli się do strajków.

${ }^{12} \mathrm{http} / / /$ codziennikfeministyczny.pl/strajk-brytyjskich-gornikow-kobiety-spolecznosc-lgbt-solidarnosc-wykuta-walce/; dostęp 25.09.2014.
} 
ramy partykularnego konfliktu klasowego, czym przyczynił się do uznania przez Partię Pracy postulatów ruchu LGBT ${ }^{13}$.

Ruchy protestu zrodzone na fali kryzysu ekonomicznego, którego symbolicznym początkiem jest upadek banku Lehman Brothers we wrześniu 2008 roku, są zapewne jeszcze trudniejsze w jednoznacznej klasyfikacji (tj. jako nowe lub stare). Fundamentem wszystkich z nich - od ulic hiszpańskich miast, przez kairski plac Tahrir, po nowojorski park Zuccottiego ${ }^{14}$ - był kryzys gospodarczy. Bezrobocie, zmniejszanie praw pracowniczych i socjalnych, degradacja usług społecznych, podwyżki cen żywności i podazżające za nimi drakońskie plany oszczędnościowe doprowadziły do masowych niepokojów. Brytyjski publicysta Paul Mason (2013), który postanowił opisać najważniejsze (w jego opinii) protesty 2011 roku, nie pozostawia wątpliwości, że u źródeł każdego z nich znajdowały się trudności gospodarcze.

W krajach Afryki Północnej zapalnikiem tak zwanej Arabskiej Wiosny był wzrost cen żywności, który spowodował, że najuboższych mieszkańców tych krajów (zwłaszcza miejskich slumsów) nie było stać na wyżywienie swoich rodzin. Wcześniej - przykładowo w Egipcie - rząd odebrał mieszkańcom kairskich slumsów jedno z głównych źródeł dochodu, komercjalizując gospodarkę odpadami w całym mieście (na Filipinach z kolei zdecydowano się na przymusową likwidację slumsów wokół Manili). W Hiszpanii i Grecji doszło do gigantycznego zadłużenia budżetów publicznych i obniżenia jakości usług publicznych połączonych z masowym bezrobociem wśród młodzieży, w tym także absolwentów szkół wyższych. W Wielkiej Brytanii okupacje budynków uniwersyteckich wywołały decyzje o podniesieniu czesnego i obcięciu zapomóg dla najbiedniejszych studentów. W sukurs studentom przyszła młodzież, która edukację akademicką miała dopiero przed sobą, a którą pozbawiono „dodatku edukacyjnego" wprowadzonego w 2004 roku przez Partię Pracy. W Stanach Zjednoczonych inspirowany hiszpańskim oburzeniem ruch Occupy Wall Street wyrósł na niezgodzie wobec astronomicznych wydatków federalnych, które zostały przeznaczone na ratowanie banków oraz firm sektora finansowego.

\footnotetext{
${ }^{13}$ Wcześniej laburzyści obawiali się otwartego zaangażowania w poparcie mniejszości seksualnych z uwagi na konserwatyzm robotników wielkoprzemysłowych, stanowiących wówczas ich główną bazę społeczna.

${ }^{14}$ Osobnego omówienia wymaga kwestia, czy protestujący w instytucjonalnych warunkach liberalnej demokracji student przejawia tę samą odwagę cywilną co ryzykujący życiem opozycjonista w obrębie dyktatury.
} 
Wszędzie kompozycja klasowa zgromadzeń przypominała mozaikę i jest niezwykle trudna do zwięzłego opisania. Zgodnie z relacjami Masona (2013) i Castellsa (2012) dominowali w nich przedstawiciele biedoty miejskiej oraz młodych ludzi, absolwentów, studentów i uczniów. Wraz z rozwojem protestów włączali się do nich także robotnicy (zwłaszcza w krajach arabskich i w Grecji) zorganizowani w związki zawodowe oraz (sporadycznie i marginalnie) partie polityczne. W wielu ruchach z 2011 roku czołowe role odgrywały kobiety, zmarginalizowani biedni, młodzi studenci oraz w niektórych przypadkach zaprawieni w bojach pracowniczych robotnicy ${ }^{15}$.

Ruchy społeczne - ruchy niezadowolenia - ostatnich kilku lat dobrze pokazują słabość podziału rozpropagowanego przez Offego. Strukturalnie rzecz ujmując, były to ruchy niehierarchiczne (Castells powiedziałby, że sieciowe), niewyłaniające liderów, o bardzo różnorodnym składzie społecznym i różnorodnych postulatach. Były to jednak ruchy wyrosłe z poczucia niesprawiedliwości mającej swoje źródła w gospodarce. „Z pewnością była to inicjatywa - pisał Castells o Oburzonych - wymierzona w bankierów i spekulantów. Naród nie zamierzał znosić konsekwencji kryzysu finansowego, którego nie wywołał. W społeczeństwie panowało głębokie poczucie niesprawiedliwości, które znalazło wyraz w protestach. Ludzie uważali, że nie należy dofinansowywać zadłużonych banków, tylko je znacjonalizować, podobnie jak uczyniono w Islandii, której przykład nieustanie przywoływano. Członkowie ruchu domagali się, żeby nieuczciwi menedżerowie trafili przed sąd. Jednomyślnie sprzeciwiali się rządowym cięciom budżetowym, zamiast tego żądając opodatkowania najbogatszych obywateli i korporacji. Powszechnie krytykowano bezrobocie milionów młodych obywateli” (2012: 127). Nieprzypadkowo członkowie ruchu Occupy Wall Street (OWS) nazywali siebie 99\%, a Castells w cytowanym powyżej fragmencie traktuje jak synonimy pojęcia: naród, społeczeństwo i członkowie ruchu. Oburzeni czy OWS z pewnościa zgłaszali (i nadal zgłaszaja) pretensje do uniwersalizmu własnych postulatów, mając poczucie występowania w roli rzeczników przytłaczającej większości obywateli, a ich postawy podczas protestów mieszczą się w definicji odwagi cywilnej.

\footnotetext{
${ }^{15}$ Egipski dziennikarz Hossem el-Hamalawy tak komentował rolę ruchu robotniczego w obaleniu Mubaraka: „Związki zawsze odgrywały kluczową rolę w mobilizacji masowej. Jeśli chcesz strajku generalnego, który pozwoli obalić dyktaturę, to nie ma nic lepszego niż wolny związek zawodowy, by to zrobić" http://www.aljazeera.com/indepth/features/2011/01/201112792728200271.html dostęp: 01.10.2014
} 


\section{/// Podsumowanie}

Przyjmując ukutą wyżej definicję odwagi cywilnej, odwołującą się do poczucia sprawiedliwości, nie ma przeszkód, żeby opór wyrastający z podstaw ekonomicznych, mający swoje źródło w przemocy ekonomicznej, również zaliczyć do odwagi cywilnej. Zatem także postulaty klasowe - jak długo odnoszą się do ideału sprawiedliwego (ekonomicznie) społeczeństwa - można traktować jako przesłankę manifestacji indywidualnych aktów odwagi cywilnej. Manifestowanie ruchu społecznego przez konflikt - przeciwstawienie się określonemu porządkowi - stanowi przy tym jeden z konstytutywnych elementów opisu ruchu społecznego (Baranowski 2013). Zawsze więc ruch będzie występował przeciw czemuś, co w ramach ruchu zostanie uznane za niesprawiedliwe, niewłaściwe i niegodne. Ostatecznie rozstrzygające, czy działanie można uznać za przejaw odwagi cywilnej, jest przyjęcie określonego modelu sprawiedliwości, odniesienie do określonych wartości i ich konkretnej definicji. Jak pisała Barbara Misztal (2007: 81): ,istnieją związki między obecnym w każdej cywilizacji punktem widzenia na to, co jest dobre, a bohaterami, jakich sobie wybiera - a także, na zasadzie analogii, jej ideałem odwagi". Jeśli odwaga cywilna aspiruje do tego rodzaju odwagi, to poszukując sprawiedliwego społeczeństwa, do jej przejawów należy zaliczyć również - budzący silne emocje, zrodzony ze wspólnych doświadczeń - opór wobec ekonomicznej niesprawiedliwości.

Znamienne, że język socjologów opisujących konflikty i podziały społeczne sięga nader często do pojęć odnoszących się do emocji. Castells (2012) pisze o strachu, gniewie rodzącym opór i entuzjazmie rodzącym nadzieje, które w sytuacji wspólnej komunikacji mogą dopiero skutkować idea, programem, postulatem. Mason (2013), podpatrując Castella oraz bohaterów swoich reportaży, pisze o oburzeniu, a czasem o rezygnacji. David Ost (2007) mówi o gniewie klasowym, mającym swoje źródło w relacjach pracy i kapitału. Guy Standing (2011) opisuje nową, niebezpieczną klasę, używając pojęcia odnoszącego się do poczucia niepewności (prekarności). Zapewne tendencja ta wymaga osobnego omówienia, ale wiele wskazuje na to, że wszystkie te pojęcia mówią o emocjach z uwagi na naruszenie szeroko akceptowanego poczucia sprawiedliwości społecznej oraz o konfliktach - także ideologicznych - jakie ten stan rzeczy wywołuje. Interpretując ten fakt w kategoriach Marksowskich, można powiedzieć, że oto sprawdza się jedna z tez Manifestu komunistycznego, mówiąca o rosnącej pauperyzacji i ujednoliceniu mas pracowników najemnych, wykluczeniu „nieprzydatnych" oraz pojawieniu się wspólnoty interesów wszystkich klas (poza bur- 
żuazją) z interesem proletariatu. Taka interpretacja powinna być jednak odczytana dialektycznie. Wspólnota oburzenia, gniewu, złości, którą obserwowaliśmy w Nowym Yorku, Barcelonie, Madrycie, Atenach, Londynie czy Kairze, pokazała, że istotnie znaczna część populacji podziela podobne emocje wobec najbogatszych i rządzących. Jednocześnie kompozycja klasowa masowych demonstracji w tych miastach była bardzo złożona. Pod względem cech agregowanych, takich jak: stosunek do własności (zarówno środków produkcji, jak i środków konsumpcji), zatrudnienie, typ wykonywanej pracy, miejsce zamieszkania, płeć, wiek, wykształcenie, ale również subiektywnych cech identyfikacyjnych, takich jak: aspiracje, poczucie przynależności, symboliczne punkty odniesienia, aspiracje polityczne - zbiorowości te były bardzo różne. Łączyło je tylko jedno - chęć życia w lepszym społeczeństwie.

Zapewne trzeba odwagi cywilnej, by o tym zamarzyć.

Bibliografia:

/// Baranowski M. 2013. Between social control and conflict. An analytical framework for social movements, „Acta Universitatis Lodziensis. Folia Sociologica”, $\mathrm{nr} 47$.

/// Castells M. 2012. Sieci oburzenia i nadziei. Ruchy społeczne w erze internetu, tłum. O. Siara, Wydawnictwo Naukowe PWN.

/// Coser A.L. 1956. The Functions of Social Conflict, Free Press.

/// Dérens J.A. 2014. Czy to poczatek, ,batkaniskiej wiosny”?, tłum. A. Dwulit, „Le Monde diplomatique. Edycja polska”, nr 3(97).

/// Greitemeyer T., Fischer P., Osswald S., Frey D. 2007. Civil courage: Implicit theories, related concepts and measurement, „The Journal of Positive Psychology", nr 2, s. 115-119.

/// Halmburger A., Baumert A., Schmitt M. 2015. Anger as driving factor of moral courage in comparison with guilt and global mood. A multimethod approach, „European Journal of Social Psychology”, nr 45, s. 39-51.

/// Henrich J.P., red. 2004. Foundations of Human Sociality. Economic Experiments and Ethnographic Evidence from Fifteen Small-Scale Societies, Oxford University Press. 
/// Inglehart R. 1997. Modernization and postmodernization. Cultural, economic and political change in 43 societies, Princeton University Press.

/// Kaczmarczyk M. 2013. Niepostuszeństwo obywatelskie a demokracja, „Studia socjologiczne", nr 1(208), s. 21-40.

/// Kiatpongsan S., Norton H.M.I. 2014. How Much (More) Should CEOs Make? A Universal Desire for More Equal Pay, http://www.hbs.edu/faculty/ Publication\%20Files/Kiatpongsan\%20Norton\%20PPS_31f17547-5033401c-8ed2-ccc9b6a2b433.pdf; dostęp: 01.10.2014.

/// Latané B., Darley J.M. 1968. When will people help in a crisis?, „Psychology Today", nr 2, s. 54.

/// Latané B., Darley J.M. 1969. Bystander „apatby”, „American Scientist”, nr 57, s. 244-268.

/// Latané B., Darley J.M. 1970. The unresponsive bystander. Why doesn't he help?, Appleton Century Crofts, Now Prentice Hall.

/// Latané B., Darley J.M. 1976. Help in a crisis. Bystander response to an emergency, General Learning Press Now Morristown.

/// Manning R., Levine M., Collins A. 2007. The Kitty Genovese murder and the social psychology of helping. The parable of the 38 witnesses, ,A American Psychologist", nr 62(6), s. 555-562.

/// Marks K. 1961. Ideologia niemiecka, tłum. K. Błeszyński, S. Filmus, [w:] K. Marks, F. Engels, Drieła, t. 3, Książka i Wiedza.

/// Mason P. 2013. Skeqd ten bunt? Nowe swiatowe rewolucje, tłum. M. Sutowski, Wydawnictwo Krytyki Politycznej.

/// Melber H. 2001. The virtues of civil courage and civil disobedience in the historical context of Namibia and South Africa, „Politikon”, nr 28(2), s. 235-244.

/// Miller W.I. 2000. The mystery of courage, Harvard University Press.

/// Misztal B. 2007. Intellectuals and the Public Good. Creativity and Civil Courage, Cambridge University Press.

/// Nowak S. 2010. Metodologia badań społecznych, PWN, s. 73-102.

/// Offe C. 1995. Nowe ruchy społeczne. Przekeraczanie granic polityki instytucjonalnej, [w:] Wtadra i spoteczeństwo. Antologia tekstów z, socjologii polityki, red. J. Szczupaczyński, Wydawnictwo Naukowe Scholar. 
/// Osswald S., Frey D., Streicher B. 2012. Moral Courage, [w:] Justice and Conflicts, red. E. Kals, J. Maes, Springer-Verlag.

/// Ost D. 2007. Klęska „Solidarności”. Gniew i polityka w postkomunistycznej Europie, tłum. H. Jankowska, Wydawnictwo Muza S.A.

/// Peisert A. 2014. Społeczeństwo obywatelskie - fenomen czy powszechnik cywilizacyjny [na podstawie rękopisu].

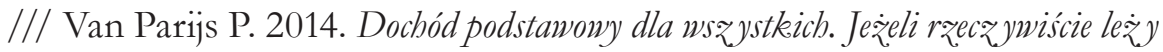
nam na sercu wolność, dajmy ludziom bezwarunkowy dochód, tłum. R. Szarfenberg. rszarf.ips.uw.edu.pl/pdf/BI_forall.pdf; dostęp: 24.02.2014.

/// Pickett K., Wilkinson R. 2011. Duch równości. Tam gdzie panuje równość, wszystkim żyje sie lepiej, tłum. P. Listwan, Wydawnictwo Czarna Owca.

/// Piskała K., Marzec W., red. 2013. Rewolucja 1905. Przewodnik Krytyki Politycznej, Wydawnictwo Krytyki Politycznej.

/// Putnam D. 1997. Psychological courage, „Philosophy, Psychiatry, and Psychology", nr 4, s. 1-11.

/// Rawls J. 1994. Teoria sprawiedliwości, tłum. M. Panufnik, J. Pasek, A. Romaniuk, Wydawnictwo Naukowe PWN.

/// Standing G. 2004. Income Security. Why unions should campaign for a basic income, „Transfer. European Review of Labour and Research”, nr 4, s. 606619.

/// Standing G. 2011. The Precariat. The New Dangerous Class, Bloomsbury Academic.

/// Swedberg R. 1999. Civil Courage (Zivilcourage). The Case of Knut Wicksell, „Theory and Society”, nr 28, 501-528.

/// Szarfenberg R. 2014. Minimalny dochód gwarantowany. http://rszarf.ips. uw.edu.pl/pdf/mdg_eapn.pdf; dostęp: 15.04.2014.

/// Wier L. 1993. Limitations of New Social Movement Analysis, „Studies in Political Economy", nr 40, s. 73-102.

/// Wiśniewski T.R. 2013. Podmiot i wolność. Driedzictwo Heglowskie i jego wrogowie, Instytut Wydawniczy Książka i Prasa. 


\section{/// Abstrakt}

Prezentowany artykuł stawia sobie za cel odpowiedź na pytanie: czy można sensownie posługiwać się pojęciem „odwaga cywilna”, nie uwzględniając pytania o ekonomiczna i społeczna przemoc oraz ich wpływ na społeczeństwo obywatelskie? Inaczej mówiąc, podjęto próbę umieszczenia odwagi obywatelskiej w kontekście interesów klasowych. Posługując się - m.in. - argumentacją Davida Osta, podjęto próbę wykazania, że wyłączenie z zakresu pojęcia odwagi cywilnej przemocy ekonomicznej ogranicza rozumienie demokracji i procesów z nią związanych.

Słowa kluczowe:

odwaga, społeczeństwo obywatelskie, gniew klasowy, demokracja

\section{/// Abstract}

The article aims to answer the question: can civil courage be sensibly discussed without questioning economic and social violence and its impact on civil society? In other words, we made an attempt to put civil courage in the context of social class interests. Using the argument presented by David Ost, we attempt to demonstrate that the exclusion of economic violence from the definition of civil courage limits our understanding of democracy and the processes related to it.

Keywords:

courage, civil society, class anger, democracy 